\title{
KEDISIPLINAN KARYAWAN PADA PT MATAHARI \\ PUTRA PRIMA Tbk
}

\author{
Oleh: Drs. H. Sugeng Hidayat,M.Si. \\ Dosen Sekretari Universitas Pamulang \\ dan \\ Deby Andreati \\ Mahasiswi Sekretari Universitas Pamulang
}

\begin{abstract}
Abstrak
Suatu perusahaan yang didirikan mempunyai beberapa tujuan, tujuan yang dimaksud adalah mencari laba, berkembang, memberi lapangan kerja, memenuhi kebutuhan masyarakat akan barang dan jasa. Tujuan perusahaan dapat dicapai apabila manajemen mampu mengelola, menggerakkan dan menggunakan sumber daya manusia yang dimilikinya secara efektif dan efisien. Perusahaan harus memikirkan tingkat absensi karena akan mempengaruhi produktivitas kerja karyawan dalam suatu perusahaan apabila tingkat perputaran dan tingkat absensi tinggi, dengan perkataan lain seringnya pegawai untuk terlambat dan tidak masuk kerja.
\end{abstract}

\section{A. Latar Belakang Masalah}

Perusahaan adalah organisasi yang merupakan kumpulan orang-orang yang bekerja sama untuk mencapai tujuan yang telah ditentukan. Peranan manusia dalam organisasi sebagai pegawai atau karyawan memegang peranan yang menentukan, karena hidup matinya organisasi semata-mata tergantung pada manusia.Karyawan merupakan faktor penting dalam setiap organisasi baik dalam pemerintah maupun swasta.

Menurut Hasibuan ( 2002 : 193 ) "Kedisiplinan adalah kesadaran dan kesediaan seseorang menaati semua peraturan perusahaan dan norma-norma sosial yang berlaku."(1)Disiplin kerja disini adalah mengenai disiplin waktu kerja dan disiplin dalam menaati peraturan yang telah ditetapkan dalam perusahaan. Dengan adanya kesadaran yang tinggi dalam melaksanakan aturan-aturan perusahaan yang diwujudkan dalam disiplin kerja yang tinggi, maka suatu produktifitas kerja juga akan tercapai.

Perusahaan tidak perlu bersikap lemah dalam menghadapi karyawan. Seorang pemimpin yang lemah bukan hanya akan mengacaukan jalannya perusahaan tetapi juga akan kehilangan rasa hormat dari para bawahannya. Menurut Heidrachman dkk (1990 : 240 ) "Selama perusahaan telah mempunyai peraturan permainan dan telah disepakati bersama, maka pelanggaran terhadap peraturan permainan ini haruslah dikenakan tindakan pendisiplinan." (1)

Kedisiplinan pegawai terhadap jam kerja sangat mempengaruhi produktivitas perusahaan. Pegawai yang bekerja sesuai dengan jam kerjanya adalah harapan 
perusahaan. Sayangnya, hal yang biasa ini justru seringkali menjadi hambatan kemajuan perusahaan.Terutama dalam suatu perusahaan absensi pegawai memegang peranan penting dalam setiap kegiatan yang dilakukan.Absensi pegawai merupakan salah satu penunjang yang dapat mendukung atau memotivasi setiap kegiatan yang dilakukan di dalam perusahaan.Disamping itu, absensi pegawai dapat juga sebagai informasi tentang bagaimana kedisiplinan pegawai yang bersangkutan, sehingga hasil dapat lebih efektif dan tepat waktu.

Faktor tenaga kerja akan menjadi sangat penting dan tinggi apabila pekerjaan mempunyai keterampilan dan keterampilan dalam melakukan pekerjaan, kekurangan kedisiplinan pegawai mengganggu tenaga kerja untuk lembur, tingkat absensi yang tinggi, pegawai yang terlambat hadir dan pegawai yang pulang awal sebelum jam kerja habis menyebabkan rendahnya produktivitas kerja yang berimbas pada pemenuhan penghargaan diri yaitu prestasi kerja. Tenaga kerja yang jumlahnya besar harus dapat di ubah menjadi asset yang bermanfaat bagi perusahaan karena tenaga kerja merupakan faktor penentu kearah tujuan yang dicapainya pada perusahaan secara efektif dan efisien untuk berbagai keterampilan dan kesempatan harus di bekalkan kepada pegawai sesuai kemampuannya tetapi masalah kepegawaian yang ada, di antaranya adalah tingginya absensi, tingginya tingkat keterlambatan jam kerja, jika suatu perusahaan tingkat absensinya tinggi kemungkinan prestasi kerja pegawai juga rendah.

Di samping itu, perusahaan harus memikirkan tingkat absensi karena akan mempengaruhi produktivitas kerja karyawan dalam suatu perusahaan apabila tingkat perputaran dan tingkat absensi tinggi, dengan perkataan lain seringnya pegawai untuk terlambat dan tidak masuk kerja. Maka produktivitas kerja pegawai akan menurun sehingga sulit bagi perusahaan dalam mencapai target yang diharapkan dan akhirnya merugikan perusahaan.

PT MATAHARI PUTRA PRIMA Tbk menuntut disiplin kerja dari karyawannya berdasarkan ketentuan yang telah di tetapkan perusahaan.Peraturan yang dibuat tersebut menunjang terhadap kelancaran kedisiplinan PT MATAHARI PUTRA PRIMA Tbk. Disiplin yang dimiliki oleh karyawan di pengaruhi oleh faktor kepuasan kerja mereka, dimana semakin puas karyawan dalam pekerjaannya maka disiplin kerja karyawan itu sendiri menjadi meningkat.

Karyawan yang sering tidak masuk kerja, akan diberikan surat peringatan dan teguran, sehingga menyebabkan PT MATAHARI PUTRA PRIMA perlu melakukan 
pembenahan kembali atas operasi PT MATAHARI PUTRA PRIMA Tbk yang sudah tentu akan menyita banyak waktu dan biaya, hal tersebut diatas jelas berpengaruh terhadap kinerja PT MATAHARI PUTRA PRIMA Tbk dalam menjalankan tugas tugasnya dan dapat menurunkan produkvitas PT MATAHARI PUTRA PRIMA Tbk sudah melakukan upaya untuk mensejahterakan karyawan butuh waktu yang cukup lama. Berdasarkan uraian diatas penulis dapat merasakan banyak kesenjangan yang penulis rasakan seperti ketergantungan para karyawan yang diberikan perusahaan.Mungkin pada dasarnya kedisiplinan kerja para karyawan sudah diterapkan sejak dikeluarkan Undang Undang Perusahaan.

Pada umumnya setiap perusahaan menginginkan adanya kemajuan dalam usaha serta berusaha untuk meningkatkan kedisiplinan dan produktivitas pegawai.Pimpinan perusahaan memberikan motivasi kepada pegawai.

Berdasarkan uraian di atas yang melatarbelakangi, penulis tertarik untuk mengetahui lebih dalam lagi tentang kedisiplinan karyawan terhadap kedisiplinan jam kerja, kehadiran karyawan, kedisiplinan karyawan dalam berbusana yang ada di PT MATAHARI PUTRA PRIMA Tbk. Maka dari itu penulisan mengambil judul “ Kedisiplinan Karyawan pada PT MATAHARI PUTRA PRIMA Tbk”.

\section{B. Identifikasi Masalah}

Dilihat dari permasalahan yang diuraikan diatas, penulis mengidentifikasikan permasalahan sebagai bahan untuk dilaporkan adalah sebagai berikut :

1. Kurangnya kedisiplinan dalam jam kerja

2. Kehadiran yang tidak sesuai dengan jadwal yang telah ditetapkan.

3. Karyawan tidak memakai pakaian sesuai dengan Standar Operasional Prosedur.

\section{Pembatasan Masalah}

Dalam suatu perusahaan atau organisasi perlu adanya kedisiplinan begitu pula kedisiplinan karyawan yang tujuannya untuk mengetahui informasi tentang bagaimana kedisiplinan pegawai yang bersangkutan, maka dari itu pembahasannya hanya dibatasi pada “ Kedisiplinan Karyawan pada PT MATAHARI PUTRA PRIMA Tbk” selama dua periode, hal ini dilakukan karena keterbatasan waktu dan menghindari pembahasan yang terlalu luas. 


\section{Perumusan Masalah}

Seorang karyawan memiliki peranan penting dalam suatu perusahaan, karyawan diharapkan mentaati setiap peraturan yang berlaku.Berdasarkan identifikasi dan pembatasan masalah di atas, maka penulis dapat merumuskan permasalahan sebagai berikut :

1. Bagaimana kedisiplinan karyawan yang dilakukan pada PT MATAHARI PUTRA PRIMA Tbk?

2. Hambatan - hambatan apa saja yang dihadapi oleh PT MATAHARI PUTRA PRIMA Tbk dalam menerapkan kedisiplinan karyawan

3. Bagaimana upaya penyelesaian yang berkaitan dengan kedisiplinan pada PT MATAHARI PUTRA PRIMA Tbk

\section{E. Pembahasan}

\section{Pengertian Disiplin Karyawan}

Di dalam kehidupan sehari-hari, dimana pun manusia berada, dibutuhkan peraturan-peraturan dan ketentuan-ketentuan yang akan mengatur dan membatasi setiap kegiatan dan perilakunya. Namun peraturan-peraturan tersebut tidak akan ada artinya bila tidak disertai dengan sanksi bagi para pelanggarnya.

Penyesuaian diri dari tiap individu terhadap segala sesuatu yang di tetapkan kepadanya, akan menciptakan suatu masyarakat yang tertib dan bebas dari kekacauankekacauan. Demikian juga kehidupan dalam suatu perusahaan akan sangat membutuhkan ketaatan dari anggota-anggotanya pada peraturan dan ketentuan yang berlaku pada perusahaan tersebut. Dengan kata lain, disiplin kerja pada karyawan sangat dibutuhkan, karena apa yang terjadi tujuan perusahaan akan sukar dicapai bila tidak ada disiplin kerja.

Singodimedjo (2002), mengatakan disiplin adalah sikap kesediaan dan kerelaan seseorang untuk mematuhi dan mentaati norma - norma peraturan yang berlaku di sekitarnya. Disiplin karyawan yang baik akan mempercepat tujuan perusahaan, sedangkan disiplin yang merosot akan menjadi penghalang dan memperlambat pencapaian tujuan perusahaan.

Menurut Terry ( dalam Tohardi, 2002 ), disiplin merupakan alat penggerak karyawan. Agar tiap pekerjaan dapat berjalan dengan lancar, maka harus diusahakan agar ada disiplin yang baik. Terry kurang setuju jika disiplin hanya dihubungkan 
dengan hal - hal yang kurang menyenangkan ( hukuman ), karena sebenarnya hukuman merupakan alat paling akhir untuk menegakkan disiplin.

Dari uraian definisi yang dikemukakan di atas, maka dapat disimpulkan bahwa disiplin kerja merupakan kegiatan dari manajemen perusahaan yang berfungsi sebagai bentuk pengendalian karyawan dalam menjalankan standar organisasional perusahaan yang teratur demi tercapainya sasaran tujuan perusahaan.

\section{Tujuan Disiplin Kerja}

Menurut Garry Dessler ( 2009 ), tujuan disiplin adalah mendorong pegawai berperilaku hati - hati dalam melakukan pekerjaan yakni berhati - hati didefinisikan sesuai peraturan dan perundang-undangan. Dalam suatu organisasi, peraturan dan perundang-undangan memiliki tujuan yang sama dengan apa yang dilakukan oleh hukum dalam masyarakat. Disiplin dibutuhkan saat satu dari peraturan dan perundang-undangan itu dilanggar.

Tujuan dari disiplin juga sebagai pendorong para pegawai untuk mencapai standar kinerja yang telah ditetapkan serta berperilaku baik dan aman di tempat kerja. Penyelia harus menganggap disiplin sebagai suatu bentuk pelatihan. Pegawai yang telah mematuhi aturan dan standar akan diberikan imbalan berupa pujian, keamanan hingga mendapatkan promosi jabatan di perusahaan. Mereka yang tidak dapat mematuhi aturan dan standar kinerja di hukum sehingga mereka mengetahui perilaku dan kinerja yang diharapkan oleh perusahaan.

\section{Pentingnya Disiplin Kerja}

Keteraturan adalah ciri utama organisasi dan disiplin adalah salah satu metode untuk memelihara keteraturan tersebut. Tujuan utama disiplin adalah untuk meningkatkan efisiensi semaksimal mungkin dengan cara mencegah pemborosan waktu dan energi.

Selain itu, disiplin mencoba untuk mencegah kerusakan atau kehilangan harta benda, mesin, peralatan dan perlengkapan kerja yang disebabkan oleh ketidakhati hatian, sendau gurau atau pencurian.

Disiplin mencoba mengatasi dan keteledoran yang disebabkan karena kurang perhatian, ketidakmampuan, dan keterlambatan. Disiplin berusaha mencegah permulaan kerja yang lambat atau terlalu awalnya mengakhiri kerja yang disebabkan karena keterlambatan atau kemalasan. Disiplin juga berusaha untuk mengatasi 
perbedaan pendapat antar karyawan dan mencegah ketidaktaatan yang disebabkan oleh salah pengertian dan salah penafsiran.

Menurut Tohardi ( 2002 ), disiplin dibutuhkan untuk tujuan organisasi yang lebih jauh, guna menjaga efisiensi dengan dan mengoreksi tindakan - tindakan individu dalam iktikad tidak baiknya terhadap kelompok. Lebih jauh lagi, disiplin berusaha untuk melindungi perilaku yang baik dengan menetapkan respons yang dikehendaki.

Meskipun bukan hal yang mustahil bahwa menghindarkan kondisi - kondisi yang memerlukan disiplin itu lebih baik daripada program pendisiplinan yang paling memuaskan, namun disiplin itu sendiri menjadi penting karena manusia dan kondisinya yang tidak sempurna, seharusnya mempunyai tujuan yang positif. Dengan demikian, dapat disimpulkan bahwa disiplin kerja sangat diperlukan untuk menunjang kelancaran segala aktivitas organisasi agar tujuan organisasi dapat dicapai secara maksimal.

Jadi, dapat disimpulkan bahwa disiplin pegawai adalah perilaku seseorang yang sesuai dengan peraturan, prosedur kerja yang ada atau disiplin adalah sikap, tingkah laku, dan pembuatan yang sesuai dengan peraturan dari organisasi baik tertulis maupun yang tidak tertulis.

\section{Faktor - Faktor Yang Mempengaruhi Disiplin Kerja}

Asumsinya bahwa pemimpin mempunyai pengaruh langsung atas sikap kebiasaan yang diperoleh karyawan. Kebiasaan itu ditentukan oleh pimpinan, baik dengan iklim atau suasana kepemimpinan maupun melalui contoh diri pribadi. Karena itu, untuk mendapat disiplin yang baik, maka pemimpin harus memberikan kepemimpinan yang baik pula.

Menurut Singodimedjo ( 2002 ), faktor yang mempengaruhi disiplin pegawai adalah :

1. Besar kecilnya pemberian kompensasi.

Besar kecilnya kompensasi dapat mempengaruhi tegaknya disiplin. Para karyawan akan mematuhi segala peraturan yang berlaku, bila ia merasa mendapat jaminan balas jasa yang setimpal dengan jerih payahmya yang telah dikontribusikan bagi perusahaan. Bila ia menerima kompensasi yang memadai, mereka akan dapat bekerja tenang dam tekun, serta selalu berusaha bekerja dengan sebaik - baiknya. Akan tetapi, bila ia merasa kompensasi yang 
diterimanya jauh dari memadai, maka ia akan berpikir mendua, dan berusaha untuk mencari tambahan penghasilan lain di luar, sehingga menyebabkan ia sering mangkir, sering minta izin keluar.

2. Ada tidaknya keteladanan pimpinan dalam perusahaan

Keteladanan pimpinan sangat penting sekali, karena dalam lingkungan perusahaan semua karyawan akan selalu memperhatikan bagaimana pimpinan dapat menegakkan disiplin dirinya dan bagaimana ia dapat mengendalikan dirinya dari ucapan, perbuatan, dan sikap yang dapat merugikan aturan disiplin yang sudah ditetapkan.

3. Ada tidaknya aturan pasti yang dapat dijadikan pegangan

Pembinaan disiplin tidak akan dapat terlaksana dalam perusahaan, bila tidak ada aturan tertulis yang pasti utnuk dapat dijadikan pegangan bersama. Disiplin tidak mungkin ditegakkan bila peraturan yang dibuat hanya berdasarkan instruksi lisan yang dapat berubah - ubah sesuai dengan kondisi dan situasi.

4. Keberanian pimpinan dalam mengambil tindakan

Bila ada seorang karyawan yang melanggar disiplin, maka perlu ada keberanian pimpinan untuk mengambil tindakan yang sesuai dengan tingkat pelanggaran yang dibuatnya. Dengan adanya tindakan terhadap pelanggar disiplin, sesuai dengan sanksi yang ada, maka semua karyawan akan merasa terlindungi, dan dalam hatinya berjanji tidak akan berbuat hal yang serupa. Ada tidaknya pengawasan pimpinan

5. Ada tidaknya perhatian kepada para karyawan

Karyawan adalah manusia yang mempunyai perbedaan karakter antara yang satu dengan yang lain. Seorang karyawan tidak hanya puas dengan penerimaan kompensasi yang tinggi, pekerjaan yang menantang, tetapi juga mereka masih membutuhkan perhatian yang besar dari pimpinannya sendiri. Keluhan dan kesulitan mereka ingin didengar, dan dicarikan jalan keluarnya, dan sebagainya. Pimpinan yang berhasil memberi perhatian yang besar kepada para karyawan akan dapat menciptakan disiplin kerja yang baik. Karena ia bukan hanya dekat dalam arti jarak fisik, tetapi juga mempunyai jarak dekat dalam artian jarak batin. Pimpinan demikian akan selalu dihormati dan dihargai oleh para karyawan, sehingga akan berpengaruh besar kepada prestasi, semangat kerja, dan moral kerja karyawan. 
6. Diciptakan kebiasaan - kebiasaan yang mendukung tegaknya disiplin

Kebiasaan - kebiasaan positif itu antara lain :

a. Saling menghormati, bila bertemu di lingkungan pekerjaan.

b. Melontarkan pujian sesuai dengan tempat dan waktunya, sehingga para karyawan akan turut merasa bangga dengan pujian tersebut.

c. Sering mengikutsertakan karyawan dalam pertemuan - pertemuan, apalagi pertemuan yang berkaitan dengan nasib dan pekerjaan mereka.

d. Memberi tahu bila ingin meninggalkan tempat kepada rekan sekerja, dengan menginformasikan, kemana dan untuk urusan apa, walaupun kepada bawahan sekalipun.

Pemimpin yang kurang baik, yang memakai kekuasaannya dengan sewenang - wenang dan menggunakan ancaman terus - menerus, kadang dapat memperoleh apa yang tampak sebagai disiplin yang baik, namun rasa gelisah dan tidak tenteram yang timbul dari peraturan yang keras dan paksaan saja, dapat meledak di muka pemimpin setiap waktu.

\section{Pelaksanaan Disiplin Kerja}

Menurut Tohardi (2002), disiplin yang paling baik adalah diri. Kecenderungan orang normal adalah melakukan apa yang menjadi kewajibannya dan menepati aturan permainan. Suatu waktu orang mengerti apa yang dibutuhkan dari mereka, di mana mereka diharapkan untuk selalu melakukan tugasnya secara efisien dengan senang hati. Kini banyak orang yang mengetahui bahwa kemungkinan yang terdapat di balik disiplin adalah meningkatkan diri dari kemalasan.

Organisaai atau perusahaan yang baik harus berupaya menciptakan peraturan atau tata tertib yang akan menjadi rambu - rambu yang harus dipenuhi oleh seluruh karyawan dalam organisasi. Peraturan-peraturan yang akan berkaitan denga disiplin itu antara lain :

1. Peraturan jam masuk, pulang, dan jam istirahat

2. Peraturan dasar tentang berpakaian, dan bertingkah laku dalam pekerjaan.

3. Peraturan cara- cara melakukan pekerjaan dan hubungan dengan unit kerja lain.

4. Peraturan tentang apa yang boleh dan apa yang tidak boleh dilakukan oleh para pegawai selama dalam organisasi dan sebagainya. (Singodimedjo, 2000)

Suatu program disiplin yang konstruktif harus dikembangkan di sekitar elemen- elemen penting sebagai berikut: 
1. Rumusan ketetapannya jelas, aturannya masuk akal, dipublikasikan, dan dijalankan secara hati- hati.

2. Pelaksanaannya adil dengan menggunakan peringatan dan hukum yang dimaklumkan, dengan tujuan memberi koreksi, seimbang dengan pelanggaran, tidak keras pada permulaan, dan ditetapkan secara seragam.

3. Kepemimpinan penyeliaan yang disesuaikan pada aturan-aturan pendisiplinan dan prosedur-prosedur, penuh pengertian tetapi teguh dalam menangani masalah pendisiplinan, dan kepemimpinan penyeliaan itu sendiri merupakan suatu contoh bagi perilaku karyawan.

4. Pelaksanaan yang adil dan seragam untuk penyelidikan pelanggaran yang tampak, di mana pelaksanaannya tergantumg pada tinjauan tingkat manajemen yang lebih tinggi, termasuk cara minta banding terhadap putusan pendisiplinan yang dianggap tidak adil. Cordon dan Watkins ( dalam Singodimedjo, 2000 )

Sesuai dengan pengertian disiplin kerja sebagai suatu sikap terhadap peraturan perusahaan dalam rangka pelaksanaan kerjanya, maka disiplin kerja dikatakan baik bila karyawan mengikuti dengan sukarela aturan atasannya dan berbagai peraturan perusahaan.Dan sebaliknya, dikatakan buruk bila karyawan mengikuti perintah atasan dengan terpaksa dan tidak tunduk pada peraturan perusahaan.

\section{Pelaksanaan Sanksi Pelanggaran Disiplin Kerja}

Pelaksanaan sanksi terhadap pelanggaran disiplin dengan memberikan peringatan, harus segera, konsisten, impersonal.

1. Pemberian Peringatan

2. Pemberian Sanksi Harus Segera

3. Pemberian Sanksi Harus Konsisten

4. Pemberian Sanksi Harus Impersonal

\section{Teknik - Teknik Pelaksanaan Disiplin Kerja}

1. Teknik Disiplin Pertimbangan Sedini Mungkin

Tindakan perbaikan sedini mungkin dari pihak manager perlunya tindakan disipliner dimasa mendatang. Jelaslah jika bahwa keadaan yang tidak baik dibiarkan memburuk, semakin sulitlah untuk mendapatkan pekerjaan yang baik dari bawahan yang tidak efektif atau tidak berkemauan penuh.

2. Teknik Disiplin Pencegahan yang Efektif 
Para manager yang menekankan apa yang harus dilakukan sebelum suatu kejadian, cenderung mendapatkan hasil yang lebih baik dari bawahan mereka. Mereka menghindari masalah disiplin dengan menciptakan disiplin yang menciptakan kondisi kerja yang akan lebih menarik para karyawan untuk bekerja dengan baik.

3. Teknik Disiplin Dengan Mendisiplinkan Diri

Tidak dapat disangkal lagi bahwa teknik disiplin yang paling penting dipelajari oleh seorang manager ialah teknik mendisiplinkan diri. Kita semua mempunyai kesukaan dan kebencian terhadap orang, kebiasaan, kaidah, peraturan dan pekerjaan kita. Namun, disiplin ini membedakan manager yang dewasa dan efektif, dengan manager yang belum dewasa dan masih harus berjuang. Disiplin diri ialah usaha seseorang untuk mengendalikan reaksi mereka terhadap keadaan yang tidak mereka senangi, dan usaha seseorang untuk mengatasi ketidaksenangannya itu.

4. Teknik Disiplin Menimbulkan Kesadaran Diri

Suatu teguran lunak dapat diberikan secara halus melalui pertanyaan tertentu pada bawahan yang jawabannya merupakan teguran otomatis bagi dirinya sendiri.

\section{Sekilas Gambaran Tentang PT MATAHARI PUTRA PRIMA Tbk}

PT Matahari Putra Prima Tbk adalah perusahaan retail Indonesia yang merupakan anak perusahaan dari perusahaan Group Lippo. PT Matahari Putra Prima Tbk ( MPPA ) didirikan 11 Maret 1986 dan mulai beroperasi secara komersial pada tahun 1986 ini mengoperasikan jaringan toko yang menjual barang - barang kebutuhan sehari - hari seperti alat tulis, buku, pakaian, aksesoris, tas, sepatu, kosmetik, peralatan listrik dan pusat hiburan keluarga yaitu Time Zone. Saat ini, MPPA mengoperasikan toko Hypermart, Foodmart dan Boston Health \& Beauty di 222 yang berlokasi di Jakarta dan kota - kota lainnya di Indonesia.

\section{Sejarah PT MATAHARI PUTRA PRIMA Tbk}

Toko pertama PT Matahari Putra Prima Tbk. terletak di Pasar Baru, Jakarta yang berdiri sejak 1958.Pada tahun 1972, toko ini kemudian berkembang menjadi perintis Departement Store pertama di Indonesia.Delapan tahun kemudian, toko dibuka di luar Jakarta yaitu di Bogor dengan Sinar Matahari Bogor.Pada tahun 1992, perusahaan melakukan IPO di Bursa Efek Jakarta dan Surabaya. Perusahaan kemudian melakukan 
ekspansi bisnis utama hingga pada tahun 2000 mampu meluncurkan kartu klub Matahari (MCC).Kantor pusat MPPA berlokasi di Menara Matahari Lantai 20 Jl. Boulevard Palem Raya No. 7 Lippo Karawaci- Tangerang Banten. Visi dan Misi. Visi Hypermart "Menjadi retailer multi format nomor satu di Indonesia". Misi Hypermart "Menjadi retailer kelas dunia yang mampu menghasilkan pertumbuhan sales organik dan profit yang mantap“

a. Struktur Organisasi PT Matahari Putra Prima Tbk

\section{Struktur Organisasi}

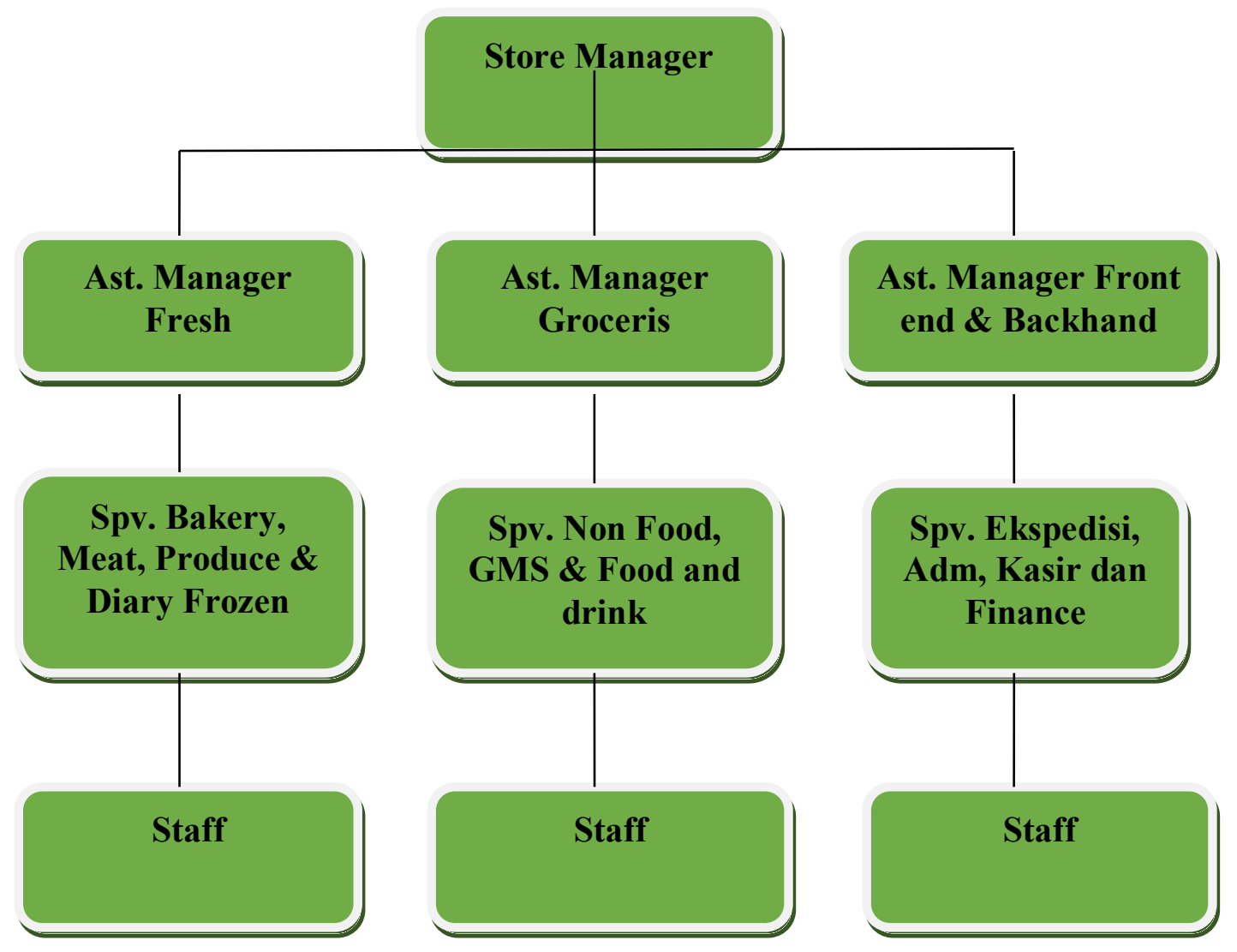

\section{F. Pembahasan dan Hasil}

Tempat pelaksanaan magang adalah PT MATAHARI PUTRA PRIMA Tbk yang di mulai pada tanggal 01 November 2014 - 31 Desember 2014.

1. Pekerjaan yang dilakukan di tempat magang

a. Melakukan pengecekan barang masuk dan keluar

b. Melakukan pengecekan kualitas barang

c. Melakukan penginputan sesuai dengan barang yang diterima

d. Mendata jumlah dan nama seluruh karyawan yang hadir 
e. Memperhatikan setiap Departemen yang ada di Perusahaan tersebut dalam kehadiran karyawan, seragam karyawan, dan jenis pekerjaan karyawan

f. Membuat laporan kehadiran bulanan

2. Hasil yang diperoleh dari magang

a. Mengetahui dunia kerja secara langsung

b. Penulis mendapatkan banyak manfaat berupa pengalaman dan pengetahuan, khususnya dalam kedisiplinan karyawan

c. Kompetensi bertambah dalam hal praktek

3. Hambatan dan cara penyelesaian dalam melakukan pekerjaan

Dari hasil magang pada PT MATAHARI PUTRA PRIMA Tbk penulis mendapatkan kesulitan dalam menghadapi pekerjaan khususnya dalam perusahaan. Adapun hambatan yang dihadapi yaitu :

a. Kesalahan menginput data

b. Kurang ketelitian dalam pengecekan barang yang sudah mendekati Exp. Date

c. Sulit untuk mengatur supplier Cara penyelesaian :

a. Harus memiliki ketelitian yang lebih dalam penginputan

b. Harus memiliki ketelitian dalam pengecekan barang

c. Para Supplier diharuskan untuk mengantri dalam pemasokan barang dan memperingatkan supplier agar kedatangan barang tidak terlambat karena akan menghambat omzet yang diinginkan Perusahaan.

\section{G. Kesimpulan}

Kedisiplinan adalah sikap kesediaan dan kerelaan seseorang untuk mematuhi dan mentaati norma - norma peraturan yang berlaku di sekitarnya. Disiplin karyawan yang baik akan mempercepat tujuan perusahaan, sedangkan disiplin yang merosot akan menjadi penghalang dan memperlambat pencapaian tujuan perusahaan. Adapun yang dapat mempengaruhi pelaksanaan disiplin kerja pada PT MATAHARI PUTRA PRIMA Tbk yaitu sebagai berikut : Kedisiplinan memegang peranan yang sangat penting dalam pelaksanaan kerja pegawai. Seorang pegawai pada PT MATAHARI PUTRA PRIMA Tbk yang mempunyai tingkat kedisiplinan yang rendah akan mempengaruhi pertumbuhan organisasi. Tidak ada tindakan disiplin yang dibuat tanpa adanya hukuman bagi pegawai yang telah melanggar aturan yang telah ditetapkan. 


\section{Daftar Pustaka}

Desceler, Gary. Manajemen Sumber Daya Manusia. Edisi ke Sepuluh jilih dua, PT Macanan Jaya Cemerlang. Jakarta. 2009.

Hasibuan.Organisasi dan Motivasi.Cetakan ke-2, Bumi Aksara. Jakarta. 2002. Hal : 193.

Rivai Veithzal. Manajemen Sumber Daya Manusia untuk Perusahaan dari Teori ke Praktik. PT Rajagrafindo Persada, Jakarta. 2004. Hal : 444.

Siagian.Kiat Meningkatkan Produktivitas Kerja. Rineka Cipta. Jakarta. 2002

Singodimedjo, Markum. Manajemen Sumber Daya Manusia.SMMAS. Surabaya. 2002.

Tohardi. Manajemen Sumber Daya Manusia. Kencana Prenada Group. Jakarta. 2002. 